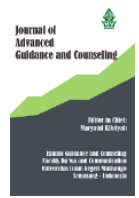 Journal of Advanced Guidance and Counseling Vol. 2 No. 1 (2021), 56-71 DOI: https://doi.org/10.21580/jagc.2021.2.1.7893 Journal Homepage \\ The description of inmates' coping skills of class IIA women's prison in Semarang
}

JAGC $\mid 56$

\author{
Elfi Rimayati ${ }^{1 *}$, Sri Sayekti ${ }^{2}$, Sri Redjeki ${ }^{3}$ \\ 1,2,3 Universitas Ivet, Semarang, Indonesia \\ Email: elfirimayati@gmail.com
}

\begin{abstract}
Purpose- The purpose of this study was to determine the coping skills of inmates in living their lives.

Method - The method used in this research was descriptive quantitative, with a population of 378 people consisting of 48 adult prisoners, 330 adult inmates. Sampling was based on the Krecjie table with a sample total of 182 people.

Result - The results of calculating the coping skills of the inmates from the five indicators that have been determined obatained an average number of $76.7 \%$. Based on the results of the average coping skills, it can be concluded that the coping skills of Class II A Women's Prison in Semarang are included in the good category.

Implications - The results of this study are expected to be input in improving correctional services at the Class IIA Women's Prison in Semarang.
\end{abstract}

Originality - This research is the study analysis coping skills of inmates in living their lives in the Class IIA Women's Prison in Semarang.

Keywords: Coping skills, inmates, women's prison.

For citation: Rimayati, E., Sayekti, S., Redjeki, S. (2021). The description of inmates' coping skills of class IIA women's prison in Semarang. Journal of Advanced Guidance and Counseling. 2(1). 56-71. https://doi.org/10.21580/jagc.2021.2.1.7893.

*Corresponding author: Elfi Rimayati (elfirimayati@gmail.com), Universitas Ivet. Jl. Pawiyatan Luhur IV nomor 17, Kota Semarang - 50233, Jawa Tengah, Indonesia. 
The description of inmates' coping skills of class IIA women's prison in Semarang

\begin{abstract}
Abstrak
Tujuan - Tujuan dari penelitian iniadalah untukmengetahui keterampilan koping narapidana dalam menjalani kehidupan mereka.

Metode - Metode yang digunakan dalam penelitian ini adalah deskriptif kuantitatif, dengan populasi 378 orang yang terdiri dari 48 tahanan dewasa, 330 narapidana dewasa. Pengambilan sampel didasarkan pada tabel Krecjie dengan total sampel 182 orang.

Hasil - Hasil penghitungan keterampilan koping narapidana dari lima indikator yang telah ditentukan ditampati jumlah rata-rata $76,7 \%$. Berdasarkan hasil ratarata keterampilan koping, dapat disimpulkan bahwa keterampilan koping dari kelas II penjara perempuan di Semarang termasuk dalam kategori baik.

Implikasi - Hasil penelitian ini diharapkan menjadi input dalam meningkatkan layanan pemasyarakatan di penjara perempuan IIA kelas di Semarang

Originalitas - Penelitian ini adalah penelitian studi keterampilan mengatasi narapidana dalam menjalani kehidupan mereka di penjara wanita IIA di Semarang.
\end{abstract}

Kata kunci: Keterampilan Coping, Narapidana, Penjara Wanita.

\title{
Introduction
}

According to Law No. 12 of 1995, the Correctional Institutions hereinafter referred to as LAPAS are places to carry out the development of inmates and students in the Correctional Institutions. While the correctional community includes inmates, correctional students, and correctional clients (BPHN, 2009). The inmates in prison are not only male but also female. Based on the data of the Directorate General of Corrections in May 2018, there were 13,569 female inmates. And in November 2017, there were only 34 prisons and 4 detention centers designed specifically for women and children. This means that only about $50 \%$ of the female inmates are accommodated in 38 facilities designed specifically for women. While the other half are in prison or men's detention centers despite being placed in separate blocks or cells (Cahyono, 2021)

The data shows the occupancy rate of women's prisons is in the high category. It also means that the rate of involvement of women in violations of legal cases is relatively high. In the study of religious literature, especially Islam, this religion highly upholds the degree of women. They are placed as the source and center of 
human civilization. Muhammad (2014) states that in women's hands, the future of the nation and humanity is staked. A popular Arabic proverb says: "Al-Mar'ah 'Imad al-Bilad, Idza Sholuhat Shaluha al-bilad, wa idza fasadat fasada al bilad" (Women are pillars of the State, if they are good, then the State will be good, if they are not good, then the State is destroyed. The word "shaluha" or "shalih" literally means good, healthy, obedient, strong, useful, peaceful, appropriate, and so on. In English, the word "shalih" means good, right, proper, sound, solid, virtuous, useful, suitable, and appropriate. Thus the meaning of "shaluha" (salih) is not limited to aspects of personal moral goodness, but also social moral goodness, physically and mentally healthy, logically intelligent, and having the ability to actualize themselves in all spaces, private, domestic, and public (Muhammad, 2014).

In line with the above thinking, Mulia asserts that Islam is also believed to be a religion that promises a better life expectancy: promising happiness and equality for people, both in the world and in the afterlife. Therefore, human has a very central place in Islamic teachings, as khalifah fi al ardh (QS. Al-Baqarah, 2:30). As khalifah of human duty: women and men are the same, including to be moral agents to make transformation efforts, for themselves, family, and society so that the ideal conditions of society are realized, termed in the Qur'an with baldatun thayyibatun wa rabbun ghafur (peaceful and happy society, full of God's grace (Mulia, 2017).

But throughout history, legal cases committed by women such as theft, embezzlement, drug abuse, murder, corruption, and various other legal cases are increasing. Based on the results of research on stress levels and reliance levels in inmates who have just entered and who will be free in the Class IIA Women's Prison in Semarang showed that the subjects of the new inmates entered with the status of the arrest of the narcotic case was 1 or $4.2 \%$, embezzlement cases were 7 or $29.2 \%$, corruption cases were 4 or $16.7 \%$, theft cases were 4 or 16.7 , other cases were 8 or $33.3 \%$. While the subjects of inmates who were immediately released, with the status of arrest from drug cases were 8 or $40 \%$, embezzlement cases were 3 or $15 \%$, corruption cases were 3 or $15 \%$, a theft case was 1 or $5 \%$, other cases were 5 or 25\% (Anggraini et al., 2019). These cases have led them to a room called 
a prison (LAPAS). In this place, they were trained to be better human beings than before.

In Indonesia, convicting is intended as a coaching effort. So that it is not only imprisonment but there is a hard effort for psychological recovery or social rehabilitation, and rebuilding social relations to all inmates. In reality, despite being JAGC | 59 a place of rehabilitation and reintegration, a prison has some drawbacks. The correctional system that is still running in Indonesia, has shortcomings, both in terms of human resources and infrastructures (Situmorang, 2019). In terms of human resources, the ratio which is not ideal between officers and the inmates becomes an obstacle in implementing the ideal correctional system. Dealing with inmates with diverse case backgrounds is hard work that carries a lot of risks. Meanwhile, for the infrastructures, overcapacity also often causes a lot of problems. According to Pratama, there are various psychological impacts experienced by the inmates, including 1 . severe depression appears 2 . Their anxiety increases 3 . They withdraw from social life. The characteristics of inmates include (1). Lack of social participation, (2) often experiencing increasingly severe mental stress with the increase of imprisonment time (3) having a tendency to close themselves socially and trying to escape from reality (4) The development of stereotyped reactions, involving quickly suspicious, irritable, quick to hate, and vengeful (5) having stigma as an untrustworthy and irresponsible human being. (6) having greater guilt and fear (Irawan, 2018).

In these conditions, inmates are required to live their lives naturally. For that, they need to learn to manage themselves (their thoughts and behaviors) well called coping. Lazaruz defines coping as a set of one's thoughts and behaviors when dealing with stressful conditions. Coping actually describes the process of cognitive activity accompanied by behavioral activities ( Lazarus \& Folkman, 1984). According to Greenberg (Lubis et al., 2015), coping behavior will arise from an individual when he or she is in a depressed or stressed state. In the model of psychoanalysis ego, coping is defined as realistic and flexible thinking and actions that solve problems so it can reduce stress (Lazarus \& Folkman, 1984). Lazaruz \& Folkman classify coping into 2, namely: approach coping and avoidance coping. Approach coping is also called Problem-Focused Coping (PFC), in which the nature is logically analytic, 
trying to solve problems by finding as much information as possible and making positive adaptations. Avoidance coping is also called Emotion-Focused Coping (EFC) with features including more repression, projection, neglecting, and having JAGC | 60 many ways to minimize the threat (Hanapi \& Agung, 2018).

The results of a study conducted by Lazaruz and Folkman (1984) on variations of the two copings, showed the existence of several coping strategies. In problemfocused coping, there are 3 kinds of strategies namely; (1) confrontative coping; (2) seeking social support, and (3) planful problem-solving. Meanwhile, for emotionfocused coping, there are 6 kinds of strategies, namely (1) seeking social-emotional support, (2) self-control, (3) distancing, (4) positive reappraisal, (5) accepting responsibility, and (6) escape or avoidance (Pratiwi \&Hirmaningsih, 2016) .

Based on the results of the pre-survey at the class IIA Women's Prison in Semarang, there was information about various problems faced by the inmates. Many of them were constrained in communicating with fellow inmates, doing an unhealthy competition in some life goals, feeling inferior, lacking confidence, often feeling hopeless, having fear and anxiety that often haunted about the acceptance of society and family after their release, disputing with families, especially children and husbands, feeling unfair regarding a period of remission, a detention room that was over capacity, getting label or negative stigma of society and others. This condition is also found in Bandung Women's Prison. This is similar to the results of research conducted on inmates in Bandung Women's Prison that showed the anxiety felt by the inmates included concerns about the public's view of an exconvict, the role of a mother for children, the acceptance of the child to her as a mother, the role of a wife to the husband, and anxiously waiting to be able to gather with family. They complained of sleeplessness, difficulty concentrating, difficulty defecating, palpitations, loss of appetite, overflowing emotions to close people, and angry suddenly (Utari et al., 2013). From this background, this study aims to describe the coping skills of inmates in living their lives in the Class IIA Women's Prison in Semarang. 


\section{Research Method}

The research method used was descriptive quantitative. Descriptive research is research that uses observations, interviews, or questionnaires about a situation regarding the subjects studied. While the approach used was quantitative, namely research methods based on the philosophy of positivism used to research on a JAGC $\mid 61$ certain population or sample, in which the data collection used research instruments, and data analysis was quantitative or static (Sugiyono, 2016).

This study took place in the Class IIA Women's Prison in Semarang. The population was 378 inmates consisting of 48 female adult prisoners and 330 female adult inmates. The sampling in this study was based on the krecjie table with a 5\% error rate or $95 \%$ confidence level. The total of the sample was 182 .

In this study, the data collection technique used questionnaires aimed to uncover data on the coping of inmates divided into five indicators. Each indicator contained 5 question items, so there were 25 questions. While the data analysis technique used descriptive analysis, where the data obtained from the questionnaire in the form of numbers were analyzed so it was obtained percentage results.

The validity test in this study used a sample of 20 respondents, where instrument testing used SPSS version 22, referring to the number of Rtable of 0.444 . The results of the calculation of the validity test of the inmates' coping variable showed that all item items were declared valid.

Meanwhile the reliability test was based on the Alpha Cronbach table of 0.05 or a significant level of $5 \%$ or a confidence level of $95 \%$. Based on the criteria of reliability coefficient of Alpha Cronbach of 0.05 or a significant level of $5 \%$, the result is 0.769 . Because 0.769 is less than 0.50 , then all items of research instruments were declared reliable. 


\section{Results and Discussion}

\section{Descriptive Analysis Result}

To find out the coping skills of inmates of Class IIA Women's Prison in Semarang, the researchers conducted an analysis of five coping indicators namely indicators of facing problems actively, planning, reducing the activeness of competition, self-control, and indicators of seeking social support. Each indicator contained 5 question items. The result of the calculation is presented in the following figure:

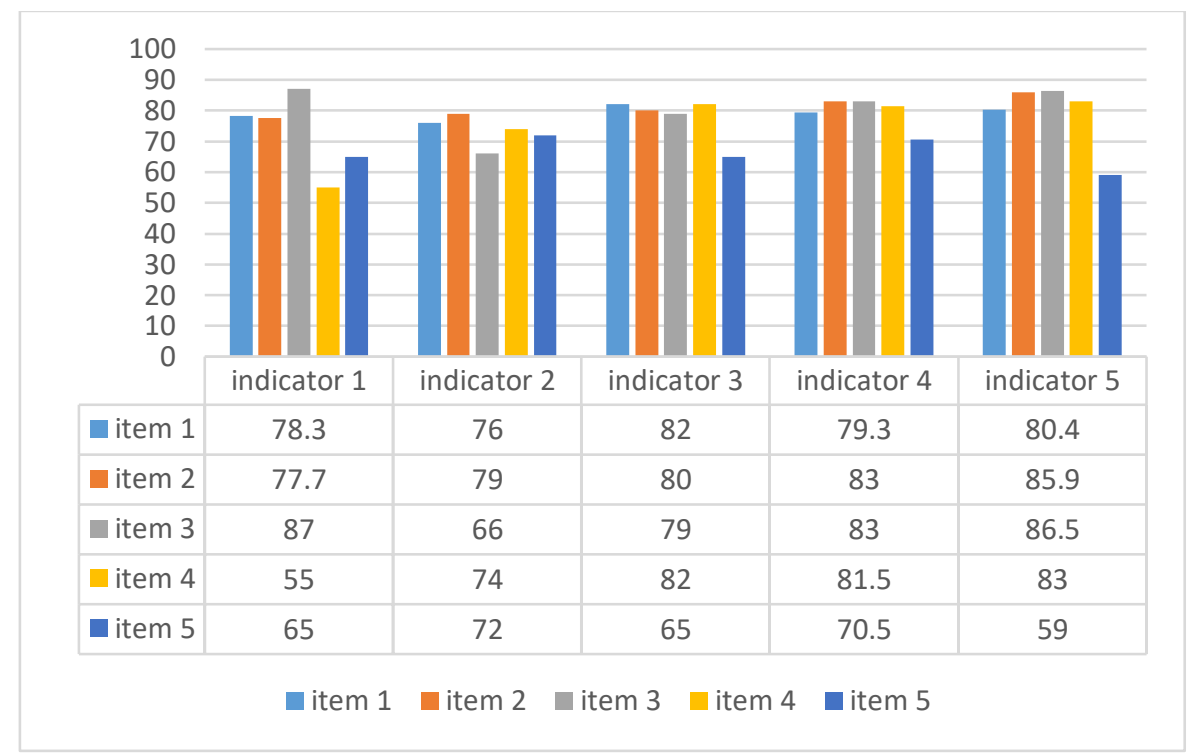

Figure 1. Descriptive Analysis of coping skills of Class IIA Women's Prison in Semarang

The first indicator is actively solving problems in which the results are as follows: focusing attention in facing problems is $78.3 \%$, looking for alternatives in solving problems is $77.7 \%$, reading books on alternatives in solving problems is $87 \%$, getting closer to God in solving problems is $55 \%$, and learning from others who have succeeded in solving problems is $65 \%$. Besides, the second indicator is having planning where the results are as follows: matures in solving problems is $76 \%$, having a priority scale in solving problems is $79 \%$, solving problems according 
to the time target is $66 \%$, having a commitment in solving problems is $74 \%$, and solving problems gradually is $72 \%$. The third indicator is reducing competition activity in which the results are as follows: "the ability that I have in solving problems" is $82 \%$, avoiding disputes with others is $80 \%$, preferring to cooperate with others in solving problems is $79 \%$, respecting the opinions of others is $82 \%$, and not hurting others is $65 \%$. Furthermore, the fourth indicator is regarding selfcontrol, in which the results are as follows: controlling emotions in solving problems is $79,3 \%$, having a positive attitude towards problems is $83 \%$, not confronting with others in solving problems is $83 \%$, being wise in making decisions is $81.5 \%$, being able to forgive themselves and others is $70.5 \%$. And the fifth indicator is regarding seeking social support where the results of each item are as follows: believing that the presence of others is important in inmates' lives is $80.4 \%$, believing the important role of the family in resolving problems is $85.9 \%$, thanking friends who want to help to solve problems is $86.5 \%$, appreciating the support of others is $83 \%$, and involving others in solving problems is $59 \%$.

From the results of the descriptive analysis of the five indicators of coping skills, then researchers conducted a discripive analysis of the coping of inmates. The results of frequency distribution calculation for inmates' coping in general are in good criteria, as stated in the table below:

Table 1. Desscriptive Analysis

\begin{tabular}{cccc}
\hline No & Indicators & Percentage & Criteria \\
\hline 1 & Actively facing problems & 73.0 & Good Enough \\
2 & Planning & 73.5 & Good Enough \\
3 & Reducing competition & 77.3 & Good \\
4 & activities & 79.5 & Good \\
5 & Self-control & 79.0 & Good \\
\hline & Average & $\mathbf{7 6 . 6 7}$ & Good
\end{tabular}

The result of the calculation of the frequency distribution of actively facing problems indicator is $73.3 \%$ categorized as good enough criteria. Meanwhile, the result of the planning indicator is $73.51 \%$, which indicates that the criteria good enough. Besides, the result of reducing competition activity indicator is $77.3 \%$, 
which shows good criteria. The self-control indicator result is $79.5 \%$, which shows good criteria. Furthermore, the indicator of seeking social support is $79.0 \%$, which indicates that inmates have good coping skills.

Based on the calculation of frequency distribution for inmates' coping skills of Class IIA Women's Prison in Semarang, the average result obtained is $76.67 \%$, categorized as good criteria. So, it can be concluded that inmates' coping skills of Class IIA Women's Prison in Semarang are relatively good.

\section{Discussion}

After obtaining an average result of $76.67 \%$ indicated good criteria, then a discussion was conducted. On the item of solving problems by focusing attention and trying to learn from the person who has successfully solved problems, the result is respectively $78.3 \%$ and $65.0 \%$ using planful problem-solving coping strategy. The results of this analysis are influenced by the behavior of inmates in solving various problems faced, due to various correctional facilities such as motivation and strengthening provided by prison officers every day when the conducting morning parade. So, they continue to improve themselves and eventually get used to solving problems independently. This strategy is one form of problem focus coping strategy, which is an effort to change the state of stress through careful steps done step by step and to conduct an in-depth analysis. This strategy is used while individuals believe that the problem can still be controlled and solved, and the individuals' resources can be possibly used to solve the problem (Lazarus \& Folkman, 1984). Bandura asserts that individuals who have confidence in their abilities will view the problem, not as a threat but as a challenge that must be faced and resolved (Vallejo et al., 2009)

The item of looking for several alternatives, the coping strategy used is accepting responsibility which is one form of emotional problem focus coping strategy, where inmates strive to manage emotions, so they can accept their own situation. Accepting responsibility itself is defined as a strong effort to be responsible to themselves for the problems that they face, and to try to accept them with relief. One of the factors that contribute to the assessment of the inmates is the existence of motivational and counseling activities provided by 
motivators, psychologists, and counselors both from inside and outside the prison conducted on a scheduled basis. This coaching leads them to a positive perception of their life orientation. In other words, positive orientation will support individuals in solving problems better, which is very important in determining the coping strategy of(Kupcewicz \&Jóźwik, 2019).

Moreover, the item of self-approach to God, the strategy used is positive reappraisal in which it is an endeavor to seek the positive meaning of each problem and to focus on self-development, and to involve in religious activities. Many of the inmates use this strategy because in this prison is held a routine spiritual activity every Friday for the inmates who are Muslims, and Sundays for those who are nonMuslims. The impact of this activity leads them to be aware of the Almighty Power of God. Pargament refers the activity as a religious approach, which is an approach by referring to the meaning of religious guidance involving The Most Holy Essence. Wong\&Wong state that each religion has a way that unique and special, which is based on the concept of religious teachings to be used as a guide in life. If one uses it for coping, then he has used coping religious, which is a coping strategy in which one believes in the greatest power outside of himself and connects him with God (Utami, 2017). Whereas Maslow defines spirituality as a stage of actualization of one's self, in which one is abundant with creativity, intuition, cheerfulness, joy, love, peace, tolerance, humility, and having a clear purpose in life. According to Maslow, spiritual experience is the highest peak that can be achieved by man and is an affirmation of his existence as a spiritual being. Spiritual experience is the highest human need. Maslow even states that spiritual experience has passed through the hierarchy of human needs (Lestari, 2019).

Further, the item regarding solving problems by reading literature or books that are in the good enough category, the inmates used coping seeking social support strategy. Social support can be direct or indirect, both oral and written form. One of the social support is information support in which it can be in the form of advice, guidance, and feedback on problem-solving (Kusrini \&Prihartanti, 2014; Hanapi \& Agung, 2018). The result of this category is good enough because in this prison, the source of reading books is still relatively few, and the inmates have a lack of reading interest. 
In the second indicator, namely planning, of the five items, two of them show good criteria that are mature in problem-solving (76\%) and having a commitment (79.0\%). While the other three items are in the good enough category including items of having a prioirity scale in solving problems (66.0\%), solving the problem in time $(74.0 \%)$, and solving the problem gradually (72.0\%). Regarding the item of maturity in solving problems, the coping strategy used is planful problem solving; where the inmates strive to solve problems through earnest efforts in overcoming the stressful situation, through careful planning, and using in-depth analysis. These results are influenced by various activities that focus on self-awareness, life motivation, and better future life orientation such as counseling, motivation training, work coaching, sports, arts, entertainment, and worship activities. These activities are very helpful for the maturity of inmates. Individuals who are able to solve problems both cognitively and behaviorally show that they have good mental health.

While the three items that are in the good enough category include having a prioirity scale in solving the problem, solving the problem in time, and solving the problem gradually. The strategy used is planful problem-solving. Although no more than $70 \%$ of inmates make efforts to be comfortable living in prison. They try to solve the problems including related to problems with the family, prison conditions, legal case problems, and other problems. People who have priority scale in solving problems, have planning, and want to solve the problems step by step are those who have good self-control.

The third indicator is reducing competition activity. On this indicator, four items are in good criteria including the ability to solve problems $(82.0 \%)$, avoiding disputes with others $(80.0 \%)$, respecting the opinions of others $(79.0 \%)$, and not hurting others (82.0\%). Meanwhile one item is categorized as good enough criteria that is happier to cooperate in solving the problems (65\%). Regarding good criteria items, they use the coping strategy of positive reappraisal (giving positive appraisal) and accepting responsibility (emphasizing problem-solving on responsibility) (Maryam, 2017) . In this case, the inmates try not to blame others, try to think positively and take wisdom from the case, and try to put the problem on a reasonable portion. Various coaching activities in this prison make them learn 
about the true meaning of life. Worship activities, productive work training, mental coaching, education (equivalency program of Paket $A, B, C$ ) are part of activities that make them more mature both in thinking and acting. For Prison itself, this coaching effort is done to prepare the inmates to be able to live a reasonable life after being declared free. In this place, they are taught to organize the future by forming a perception of the orientation of the future.

The fourth indicator is self-control. There are four items that are in the good category, including being able to control emotions $(79.3 \%)$, having a positive attitude towards the problems (83.0\%), being wise in making decisions (83.0\%), and forgiving themselves and others (81.5\%). Meanwhile one item is categorized as good enough that is not confronting with others (70.5\%). In the item of ability to control emotion, thecoping strategy used is self-controlling which is reacting by doing regulation in both feelings and actions (Maryam, 2017). Besides, Items regarding having a positive attitude towards problems, forgiving themselves and others use the positive reappraisal coping strategy which is conducting selfdevelopment efforts through positive activities. Moreover, the item of being wise in making decisions use accepting responsibility coping strategy that is raising awareness of the role of themselves in solving the problems faced (Maryam, 2017). Some forms of coaching activities that contribute to the results of this assessment are activities of providing life motivation (happy, healthy, prosperous), counseling, awareness through religious activities both scheduled and tentative as well as various activities of togetherness (such as sports, art performances, and competitions). All of these activities lead inmates to subjective well-being. According to Diener, Lucas \& Oishi, an individual is judged to have high subjective well-being when he feels more pleasant emotions than unpleasant emotions, feels involved in interesting and enjoyable events, and when he is satisfied with his life (Tolewo et al., 2019).

The fifth indicator is seeking social support. In this indicator, four items are categorized as good criteria in which the items are believing that the presence of others is important (80.4\%), believing the important role of the family $(85.9 \%)$, thanking friends who help (86.5\%) as well as appreciating the support of others (83.0\%). While the item of involving others in solving the problems $(59.0 \%)$ is 
categorized as good enough criteria. These results show that the inmates use two coping strategies at once, namely seeking social support, which is one form of problem-focused coping strategy and seeking social-emotional support which is one form of emotional-focused coping strategy. Seeking social support is a form of coping strategy in which in solving the problem, the individual tries to seek and get support from outside of himself or his social environment. While seeking socialemotional support is an individual's effort in solving problems by seeking emotional and social support from others (Maryam, 2017).

Robert \& Gilbert state that social support can be interpreted as a situation that benefits the individual obtained from a trusted person. From here, he will understand that others give attention, appreciation, and love. It is also the best thought which is a multidimensional construct consisting of functional and structural components (Kusrini \&Prihartanti, 2014).

Safarino states that there are four aspects of social support, namely (1) emotional support such as feeling loved, being cared for so that an individual feels comfortable. (2) award support which is support by giving a positive assessment, such as a statement of agreement. (3) instrumental support which is support provided by providing direct financial assistance or helping to complete tasks. (4). Information support; can be advice, guidance, feedback on problem-solving (Kusrini \&Prihartanti, 2014). These four forms of social support contribute positively to helping individuals in solving problems. Ryff \& Keyes affirms that social well-being describes psychologically healthy individuals. They divided it into six main dimensions, including having a positive relationship quality with others, positive self-acceptance, having a purpose in life, the ability to grow personally, interacting effectively with the environment, and becoming an independent or autonomous person (Cyntia \& Aruum, 2017). Social support according to Pugliesi is also associated with subjective well-being among others because it has a role in overcoming feelings of distress, contributing to a decrease in the adverse effects of psychological stress and other stress problems phenomena (Muarifah et al., 2019). Thus, social support is very important in every life of individuals, especially those who are having life problems. 
The description of inmates' coping skills of class IIA women's prison in Semarang

\section{Conclusion}

The results of this study show that the inmates of Class IIA Women's Prison in Semarang have coping skills with good categories. The average results of the five indicators, including actively facing problems, planning, reducing competition activities, self-control, and seeking social support are categorized into the good JAGC | 69 category. The results are influenced by various coaching activities, as well as the culture of life applied in the prison. The results of this study can be used by Class IIA Women's Prison in Semarang in improving and developing the model of coaching, adding facilities and infrastructures such as the addition of more varied reading books, the addition of buildings or rooms, and the addition of officers.

\section{References}

Anggraini, D., Hadiati, T., \& Widodo. (2019). Perbedaan tingkat stress dan tingkat resiliensi narapidana yang baru masuk dengan narapidana yang akan segera bebas (studi pada narapidana di Lembaga Pemasyarakatan Kelas IIA Wanita Semarang). Jurnal Kedokteran Diponegoro, 8(1). https://doi.org/10.14710/dmj.v8i1.23308.

BPHN. (2009). UU RI tentang pemasyarakatan tahun 1995. www.bphn.go.id

Cahyono, K. (2021). Perlindungan harkat dan martabat warga binaan pemasyarakatan perempuan di Rutan Kelas IIB Banyumas. JUSTITIA : Jurnal IImu Hukum Dan Humaniora, 8(2), 247-253. http://dx.doi.org/10.31604/justitia.v8i2.247-253.

Cyntia, S, W., \& Arruum L, R. (2017). Mindfulness dan kesejahteraan psikologis pada remaja. Psikohumaniora: Jurnal Penelitian Psikologi, 2(1), 43-59. https://doi.org/10.21580/pjpp.v2i1.1323.

Hanapi, I., \& Agung, I. M. (2018). Dukungan sosial teman sebaya dengan self efficacy dalam menyelesaikan skripsi pada mahasiswa. Jurnal RAP UNP, 9(1), 37-45. https://doi.org/10.24036/rapun.v9i1.10378.

Irawan, R. (2018). Konsep diri warga lembaga pemasyarakatan. SCHOULID: Indonesian Journal of School Counseling, 3(2), 41-45. http://dx.doi.org/10.23916/08423011.

Kupcewicz, E., \& Jóźwik, M. (2019). Positive orientation and strategies for coping with stress as predictors of professional burnout among Polish nurses. International Journal of Environmental Research and Public 
Elfi Rimayati, Sri Sayekti, Sri Redjeki

Health, 16(21), 4264. https://doi.org/10.3390/ijerph16214264.

Kusrini, W., \& Prihartanti, N. (2014). Hubungan dukungan sosial dan keperceyaan diri dengan prestasi bahasa inggris siswa kelas VIII SMP Negeri 6 Boyolali. Jurnal Penelitian Humaniora, 15(2), 131-140. https://doi.org/10.23917/humaniora.v15i2.673.

Lazaruz, R, S \& Folkman, P. D. (1984). Stress, Appraisal, and Coping. Springer Publishing Company, Inc.

Lestari, Y. I. (2019). Bagaimana pengasuhan spiritual mampu membangun karakter yang baik pada remaja muslim? Jurnal Psikologi, 15(2), 108120. http://dx.doi.org/10.24014/jp.v15i2.7794.

Lubis, R., Irma, N. H., Wulandari, R., Siregar, K., Tanjung, A., Wati, T. A., N, M. P., \& Syahfitri, D. (2015). Coping stress pada mahasiswa yang bekerja. Diversita, 200. https://doi.org/10.31289/diversita.v1i2.494.

Maryam, S. (2017). Strategi coping: Teori dan sumberdayanya. JURKAM: Jurnal Konseling Andi Matappa, 1(2), 101-107. https://dx.doi.org/10.31100/jurkam.v1i2.12.

Muarifah, A., Widyastuti, D. A., \& Fajarwati, I. (2019). The effect of social support on single mothers' subjective well-being and its implication for counseling. Jurnal Kajian Bimbingan Dan Konseling, 4(4), 143-149. http://dx.doi.org/10.17977/um001v4i42019p143.

Muhammad, H. (2014). Islam dan pendidikan perempuan. Jurnal Pendidikan Islam, 3(2), 231-244. https://doi.org/10.14421/jpi.2014.32.231-244.

Mulia, M. (2017). Pedagogi feminisme dalam perspektif islam. Journal of Chemical Information and Modeling, 53(9), 21-25..

Pratiwi, A. C., \& Hirmaningsih, H. (2016). Hubungan coping dan resiliensi pada perempuan kepala rumah tangga miskin. Jurnal Psikologi, 12(2), 68-73. http://dx.doi.org/10.24014/jp.v12i2.3231.

Situmorang, V. H. (2019). Lembaga pemasyarakatan sebagai bagian dari penegakan hukum. Jurnal Ilmiah Kebijakan Hukum, 13(1), 85. http://dx.doi.org/10.30641/kebijakan.2019.V13.85-98.

Sugiyono, P. D. (2016). Metode penelitian kuantitatif, kualitatif, dan R\&D. Alfabeta.

Tolewo, S. P., Kurnaningsih, Y., \& Setiawan, A. (2019). The Influence of social 
The description of inmates' coping skills of class IIA women's prison in Semarang

support and self esteem on subjective well-being in elderly of pamona utara sub-district Poso Regency. PSIKODIMENSIA, 18(1), 67-73. https://doi.org/10.24167/psidim.v18i1.1789.

Utari, D. I., Fitria, N., Rafiyah, I., Keperawatan, F. I., \& Padjajaran, U. (2013). Gambaran tingkat kecamasan pada warga binaan wanita menjelang bebas di lembaga pemasyarakatan wanita klas II A Bandung. Jurnal Ilmu Keperawatan, 1(1), 33.

Vallejo, P, M., Comeche Moreno, M., Ortega Pardo, J., Rodríguez Mu ? oz, M., \& Díaz García, M. (2009). Las expectativas de autoeficacia y el ajuste emocional en el afrontamiento de la fibromialgia. Escritos de Psicología, 2(2), 28-34. 